\author{
Roberta Rossi* - Paolo SAVOLDELLI** - Roberto SINDACO***
}

\title{
Climate change and species distribution: the case of Calopteryx haemorrhoidalis (Odonata Calopterygidae) in Piedmont (Italy)
}

\begin{abstract}
Riassunto: Cambiamenti climatici e distribuzione delle specie: il caso di Calopteryx haemorrhoidalis (Odonata Calopterygidae) in Piemonte (Italia) I cambiamenti climatici influenzano le specie e i sistemi biologici in vari modi ed è documentato che sono responsabili di variazioni nella distribuzione delle specie. Gli Odonati hanno mostrato di rispondere prontamente ai cambiamenti climatici e varie specie mediterranee negli ultimi anni hanno esteso il proprio areale verso nord in Europa. In questa nota, riportiamo le prime segnalazioni di popolazioni riproduttive di Calopteryx haemorrhoidalis in Piemonte (Italia nord-occidentale), che suggeriscono uno spostamento verso nord dell'areale della specie in Italia. Sono inoltre ricordati i casi di altre specie di libellule mediterranee che, negli ultimi anni, sono state segnalate per la prima volta in Piemonte.
\end{abstract}

\begin{abstract}
Climate change affects species and biological systems in several ways and is documented to be responsible of species distribution shifts. Odonata are reported to respond quickly to climate change, and in last years several Mediterranean species have expanded their range northwards in Europe. In this note, we report the first records of reproductive populations of Calopteryx haemorrhoidalis in Piedmont (NW Italy), suggesting a northwards latitudinal shift of the range of the species in Italy. The reports of Mediterranean dragonflies and damselflies that in the last years have been recorded for the first time in Piedmont are also outlined.
\end{abstract}

Key words: Dragonflies, damselflies, distribution, Piedmont, Italy, reproductive populations, climate change.

Climate change is documented to affect species and biological systems in several ways, in particular causing changes in physiology, phenology, local abundance and distribution of species and altering interspecific interactions such as the ones in predator-prey, insect-plant and host-parasite systems, with effects on both biological and human communities (Parmesan, 2006; Pounds et al., 2006; Hassell \& Thompson, 2008; Ludovisi et al., 2014; Pecl et al., 2017).

Distribution shifts can occur in latitude and elevation: range shifts towards the Poles and the top of the mountains have been widely documented (Parmesan, 2006). The spatial responses of species to climate change may be influenced by mode of dispersal; Odonata are found to respond so strongly to be proposed as candidate macroecological barometers for global climate change (Hassall, 2015).

In Europe, many species of Mediterranean Odonata, such as Crocothemis erythraea (Brullé, 1832), Aeshna affinis Vander Linden, 1820, Anax parthenope (Selys-Longchamps, 1839), Orthetrum brunneum (Fonscolombe, 1837), Erythromma lindenii (Selys-Longchamps, 1840), Erythromma viridulum
(Charpentier, 1840) and others, have expanded their range northwards (Ott, 2001, 2010).

In this note, we report the first records of reproductive populations of the Mediterranean Calopteryx haemorrhoidalis (Vander Linden, 1825) in Piedmont (North-West Italy), a region characterized by a Continental climate, suggesting a northwards latitudinal shift of the range of the species in Italy.

In 2015 we found 6 individuals of C. haemorrhoidalis in Vallumida (Montegrosso d'Asti, Asti Province, Piedmont, 17.VII.2015, PS) (Fig. 1) and more than 10 specimens of $C$. haemorrhoidalis in the Rio Miseria (a small tributary of the Erro River, Alessandria Province, Piedmont, 18.VII.2015, RS). In 2016 we found 2 individuals near Triasca (Agliano Terme, Asti Province, Piedmont, 15.VII.2016, PS) and 2 individuals near Biolla (Montegrosso d'Asti, Asti Province, Piedmont, 15.VII.2016, PS). The latter two sites are located very close $(1.5-2 \mathrm{~km})$ to the Vallumida one. In the Rio Miseria valley the occurrence of the species has been confirmed also two years later (2.VII.2017; RS and RR) (Fig. 2).

C. haemorrhoidalis was already known from

${ }^{*}$ Roberta Rossi, via Fatebenefratelli 4, 10137 Torino, Italy. E-mail: robertarossipg@gmail.com

** Paolo Savoldelli, Istituto per le Piante da Legno e 1'Ambiente, corso Casale 476, 10132 Torino, Italy. E-mail: savoldelli@ipla.org

${ }^{* * *}$ Roberto Sindaco, Istituto per le Piante da Legno e l'Ambiente, corso Casale 476, 10132 Torino, Italy. E-mail: sindaco@ipla.org 
Piedmont and Aosta Valley only from isolated records (Fig. 2): a specimen labelled "Gressoney La Trinité" (Valle d'Aosta, M. Lanza leg.) collected in July 1970 is preserved in the "La Specola" Museum in Florence (Terzani, 2003). After, a male was collected in the Natural Reserve "Sorgenti del Belbo" near Montezemolo (Cuneo Province, 30.VII.1994, M. Pavesi). More recently a specimen was recorded near Bagnasco (Cuneo Province, VI.2011, Gianpiero Secco, "Giansacca", obs.; Forum Natura Mediterraneo, 2011) and another one near Trinità (Cuneo Province, 15.VIII.2013, M. Pettavino obs.). These records, however, being based on single specimens and not confirmed by further observations, were interpreted as referable to vagrant specimens. Recently

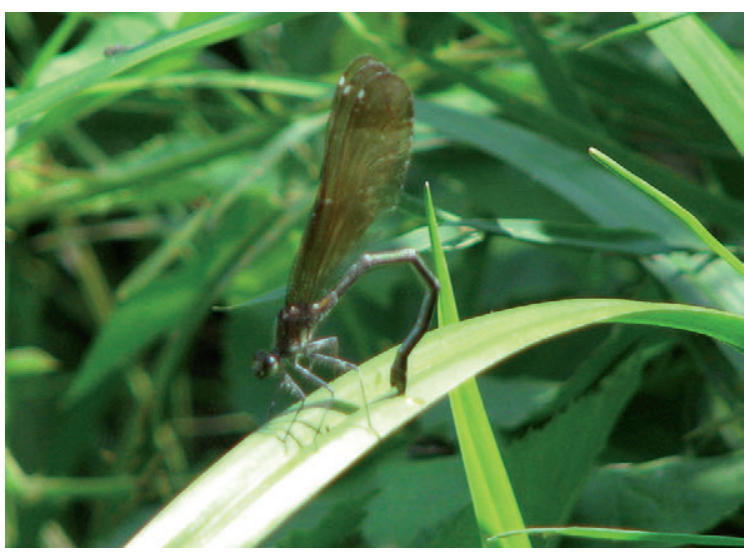

Fig. 1. Female of C. haemorrhoidalis in oviposition (Vallumida, 17.VII.2015, photo by P. Savoldelli).

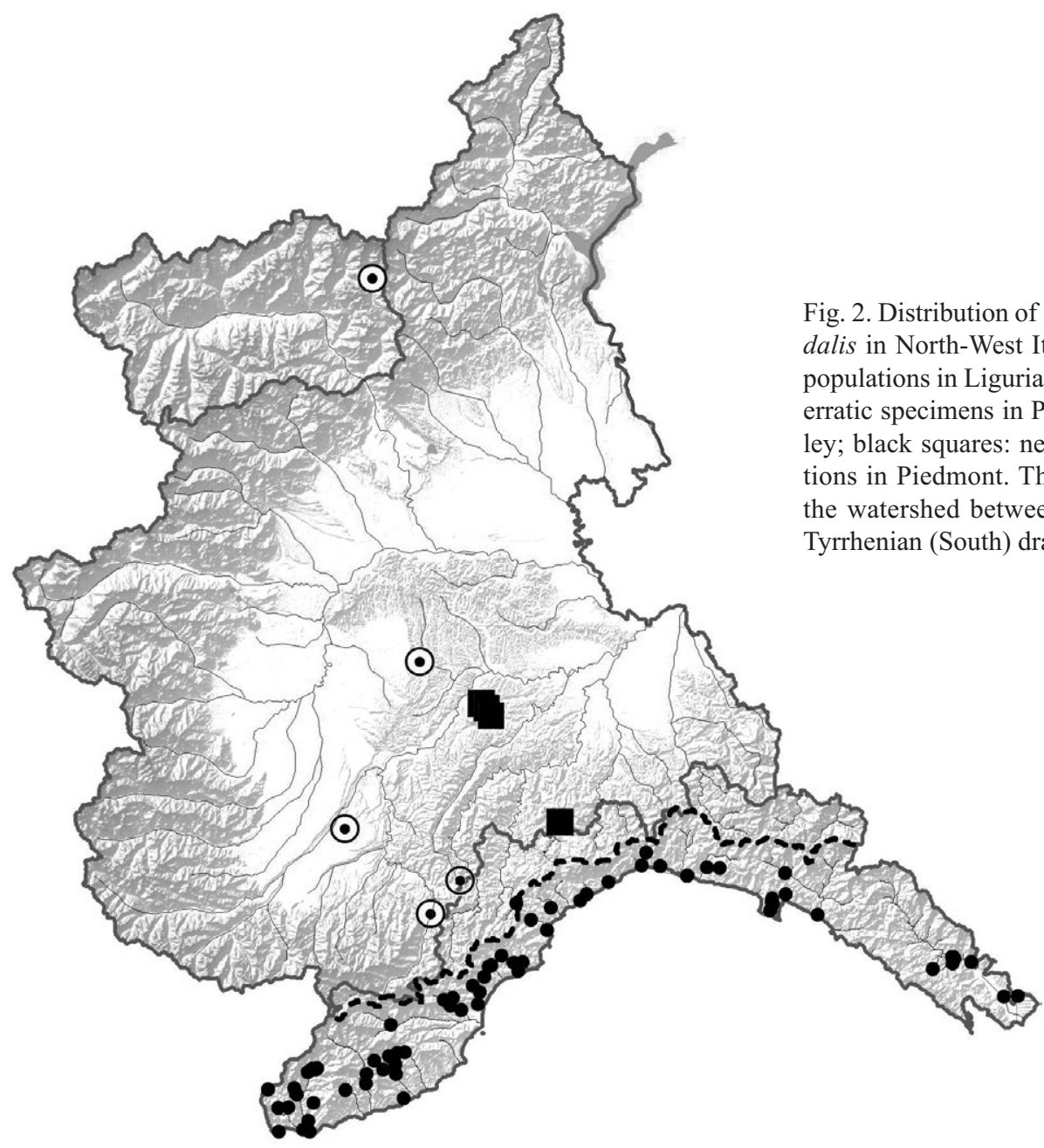


a male was photographed during a quick survey near Cantarana (Asti Province, 20.VI.2018, RS), but in this case it is not yet possible to establish whether it was a vagrant individual, or if there is a population in the area.

The nearest established populations are found in Liguria (Fig. 2), where the species is widespread in several streams of the Tyrrhenian drainage basin (Ottonello \& Oneto, 2013). Only one record in Liguria is located in the Adriatic drainage basin, the Bormida River at Altare (Savona Province, 1970; Bordoni et al., 1980), where the presence of the species has no longer been confirmed ever since.

In the Po plain, the nearest populations occur in Emilia Romagna, in the Modena province (Riservato et al., 2014).

The recently discovered Piedmontese populations of C. haemorrhoidalis have probably established in very recent years. The Rio Miseria was repeatedly surveyed in the last years for monitoring Odonata by the authors and other naturalists, with no observations of C. haemorrhoidalis before 2015. Moreover, some localities in the area around Montegrosso d'Asti were surveyed by Barbero (2005) with no evidence of the species occurrence.

In the last decade, other species of Mediterranean dragonflies and damselflies have been recorded for the first time in Piedmont: consistent field data support the newly established presence of Coenagrion scitulum (Rambur, 1842) (Evangelista, 2009; Barbero \& Baldizzone, 2010) and Selysiothemis nigra (Vander Linden, 1825) (Subrero, 2014), but also Coenagrion caerulescens (Fonscolombe, 1838) (first record 2005; Boano et al., 2007) has likely extended its range in Piedmont in recent times.

In conclusion, this note highlights the following:

1) The Piedmont Odonatofauna has been enriched of one species, C. haemorrhoidalis.

2) Our findings suggest that processes acting on global scale, such as climate change, are producing biological effects detectable also on both regional and national scale; in particular, our findings suggest that distribution range of $C$. haemorrhoidalis in Italy is most likely expanding northwards as a consequence of climate change.

3) Future research effort should be focused on the inner parts of the Po plain to evaluate possible northwards range shifts of other Mediterranean species in the context of climate change.

\section{ACKNOWLEDGMENTS}

We thank Maurizio Pavesi and Massimo Pettavino for providing information about records on occurrence of vagrant individuals of $C$. haemorrhoidalis in Cuneo Province, and Alberto Venchi (Australian Biological Resources Study, Canberra, Australia) for the English review of the manuscript, and the referees for their useful comments.

\section{REFERENCES}

BArbero R., 2005 - Le libellule della provincia di Asti (Piemonte, Italia) (Insecta Odonata). Rivista Piemontese di Storia Naturale, 26: 129-188.

BArbero R., BALdizzone G., 2010 - Sulla presenza di Coenagrion scitulum (Rambur, 1842) in Piemonte (Odonata: Zygoptera, Coenagrionidae). I Quaderni di Muscandia, 9: 107-111.

Boano G., Sindaco R., Riservato E., Fasano S., Barbero R., 2007 - Atlante degli Odonati del Piemonte e della Valle d'Aosta. Memorie dell'Associazione Naturalistica Piemontese, 6: 1-160.

Evangelista M., 2009 - Segnalazioni faunistiche italiane. 483. Coenagrion scitulum (Rambur, 1842) (Odonata Coenagrionidae). Bollettino della Società entomologica italiana, 141(2): 113.

ForUm NATURA MEDITERRANEO, 2011 - https://www.naturamediterraneo.com/forum/topic.asp?TOPIC ID=147274

Hassall C., Thompson D.J., 2008 - The impacts of environmental warming on Odonata: a review. International Journal of Odonatology, 11: 131-153.

HASSALl C., 2015 - Odonata as candidate macroecological barometers for global climate change. Freshwater Science, 34: 10401049.

Ludovisi A., Rossi R., Paracucchi R., Selvaggi R., Fagotti A., Simoncelli F., Pascolini R., Di Rosa I., 2014 - The delayed effects of meteorological changes on the water frogs in Central Italy. Hydrobiologia, 730: 139-152.

Отт J., 2001 - Expansion of Mediterranean Odonata in Germany and Europe: consequences of climate changes. In Walther, G.R., C. A. Burga \& P. J. Edwards (eds), 'Fingerprints' of Climate Change: Adapted Behaviour and Shifted Species Ranges. Kluwer Academic/Plenum Publishers, New York, Boston, Dordrecht, London, Moscow: 89-111. 
Oтт J., 2010 - Dragonflies and climatic change - recent trends in Germany and Europe. BioRisk 5: 253-286.

Ottonello D., Oneto F., 2013 - Libellule di Liguria (Odonata). Annali del Museo Civico di Storia Naturale "G. Doria”, Genova, 105: 297-425.

PARMESAN, 2006 - Ecological and evolutionary responses to recent climate change. Annual Review of Ecology, Evolution, and Systematics, 37: 637-69.

Pecl G. T., Araujo M.B., Bell J., Blanchard J., Bonebrake T. C., Chen I., Clark T. D., Colwell R.K., Danielsen F., EvenGARD B., RoBINSON S. et al., 2017 - Biodiversity redistribution under climate change: Impacts on ecosystems and human well-being. Science, 355(6332): 1-9.

Pounds J.A., Bustamante M.R., Coloma L.A., Consuegra J.A., Fogden M.P.L., Foster P.N., La Marca E., Masters K.L., Merino-Viteri, Puschendorf R., Ron S.R., SÁnchez-Azofeifa G.A., Still C.J., Young B.E., 2006 - Widespread amphibian extinctions from epidemic disease driven by global warming. Nature, 439: 161-167.

Riservato E., Festi A., Fabbri R., Grieco C., Handersen S., La Porta G., Landi F., Siesa M.E., Utzeri C., 2014 - Odonata - atlante delle libellule italiane - preliminare. Società Italiana per lo Studio e la Conservazione delle Libellule, Edizioni Belvedere, Latina "le scienze" (17), 224 pp.

Subrero E., 2014 - Selysiothemis nigra (Vander Linden, 1825) (Odonata: Libellulidae): riproduzione accertata in Piemonte. Rivista piemontese di Storia naturale, 35: 99-108.

TERZANI F., 2003 - Segnalazioni faunistiche italiane. Bollettino della Società entomologica italiana, 135(3): 189-192. 